\title{
The carbonate system in the North Sea: Sensitivity and model validation
}

\author{
Yuri Artioli a,*, Jeremy C. Blackford a , Momme Butenschön ${ }^{a}$, Jason T. Holt ${ }^{\mathrm{b}}$, Sarah L. Wakelin ${ }^{\mathrm{b}}$, \\ Helmuth Thomas ${ }^{c}$, Alberto V. Borges ${ }^{\mathrm{d}}$, J. Icarus Allen ${ }^{\mathrm{a}}$ \\ a Plymouth Marine Laboratory, Prospect Place, Plymouth, PL1 3DH, UK \\ ${ }^{\mathrm{b}}$ National Oceanography Centre, 6 Brownlow Street, Liverpool, L3 5DA, UK \\ c Dalhousie University, Department of Oceanography, Halifax, Canada \\ ${ }^{d}$ Université de Liège, Unité d'Océanographie Chimique, B-4000, Belgium
}

\section{A R T I C L E I N F O}

\section{Article history:}

Received 7 September 2011

Received in revised form 20 April 2012

Accepted 25 April 2012

Available online 5 May 2012

\section{Keywords:}

Ocean Acidification

Model validation

North Sea

$\mathrm{pH}$

Alkalinity

\begin{abstract}
A B S T R A C T
The ocean plays an important role in regulating the climate, acting as a sink for carbon dioxide, perturbing the carbonate system and resulting in a slow decrease of seawater $\mathrm{pH}$.

Understanding the dynamics of the carbonate system in shelf sea regions is necessary to evaluate the impact of Ocean Acidification (OA) in these societally important ecosystems. Complex hydrodynamic and ecosystem coupled models provide a method of capturing the significant heterogeneity of these areas. However rigorous validation is essential to properly assess the reliability of such models. The coupled model POLCOMS-ERSEM has been implemented in the North Western European shelf with a new parameterization for alkalinity explicitly accounting for riverine inputs and the influence of biological processes. The model has been validated in a like with like comparison with North Sea data from the CANOBA dataset. The model shows good to reasonable agreement for the principal variables, physical (temperature and salinity), biogeochemical (nutrients) and carbonate system (dissolved inorganic carbon and total alkalinity), but simulation of the derived variables, $\mathrm{pH}$ and $\mathrm{pCO}_{2}$, are not yet fully satisfactory. This high uncertainty is attributed mostly to riverine forcing and primary production. This study suggests that the model is a useful tool to provide information on Ocean Acidification scenarios, but uncertainty on $\mathrm{pH}$ and $\mathrm{pCO}_{2}$ needs to be reduced, particularly when impacts of $\mathrm{OA}$ on ecosystem functions are included in the model systems.
\end{abstract}

(c) 2012 Elsevier B.V. All rights reserved.

\section{Introduction}

In the last 10 years a significant body of marine and climate research has shown that the increase in atmospheric $\mathrm{CO}_{2}$ concentration is causing not only the well-known phenomenon of global warming, but is also leading to a change in the oceanic carbonate system termed Ocean Acidification ( $\mathrm{OA}$ ) resulting in, amongst other changes, a decrease of $\mathrm{pH}$ (Caldeira and Wickett, 2003).

Oceans are indeed a significant sink for anthropogenic $\mathrm{CO}_{2}$, having absorbed about $48 \%$ of the anthropogenic emissions throughout the industrial era (Sabine et al., 2004) and will continue to absorb a significant proportion of future emissions. Adding $\mathrm{CO}_{2}$ to seawater disrupts the carbonate system, leading to an increase in free $\mathrm{CO}_{2} /$ carbonic acid and the bicarbonate ion concentration while decreasing the carbonate ion, pH and carbonate saturation states (Zeebe and Wolf-Gradow, 2001). All of these have implications for a range of biological and chemical processes like calcification, primary production and reproduction (Blackford, 2010; Doney et al., 2009; Fabry et al., 2008; Pörtner, 2008; Society, 2005). This general trend predicted by chemical models has been confirmed by

\footnotetext{
* Corresponding author. Tel.: + 4401752633417.

E-mail address: yuti@pml.ac.uk (Y. Artioli).
}

several long term observational data sets such as the Hawaiian Ocean Time series (HOT/ALOHA, Dore et al., 2009), the Bermuda Atlantic Time series Studies (BATS, Bates, 2007) and the European Station for Time Series in the Ocean (ESTOC, Santana-Casiano et al., 2007) where a consistent decrease of about $0.02 \mathrm{pH}$ units in the last 20 years has been observed.

Several models have been implemented to forecast the future state of the carbonate system under different emission scenarios (Feely et al., 2009; Orr et al., 2005): depending on the scenarios and the structure of the model, they consistently predict a decrease of surface $\mathrm{pH}$ on the global ocean of about $0.3-0.4 \mathrm{pH}$ units by 2100 , corresponding to a decrease of about $40-50 \%$ of carbonate ions in the seawater. Global oceanic models show significant spatial variability with the Polar regions, in particular the Arctic, exhibiting more vulnerability because of temperature effects (Steinacher et al., 2009).

Even higher spatial and temporal variability can be observed in shelf seas and reef systems (Blackford and Gilbert, 2007; Santos et al., 2010; Thomas et al., 2004) as a result of several concurrent processes. Primary productivity is often high in these areas leading to a large drawdown of dissolved inorganic carbon (DIC, the sum of $\mathrm{CO}_{2}$, bicarbonate and carbonate ions) and consequent rise of $\mathrm{pH}$ (Thomas et al., 2005). Due to the shallow depth, benthic processes can also significantly affect the pelagic carbon cycle and alkalinity (Thomas et al., 
2009). Finally terrestrial inputs, in particular from rivers, can inject significant loads of DIC and total alkalinity (TA) into coastal systems strongly driving the carbonate system (Borges and Gypens, 2010; Gypens et al., 2011).

Simulating all these processes in requisite detail in a biogeochemical model is a significant challenge and requires a relatively complex coupled hydrodynamic-ecosystem-carbonate model.

Given the high variability in the physical, chemical and biological dynamics of the shelf seas and the relative complexity of these models, it is particularly important to rigorously validate such a model to prove the ability to reproduce the major patterns of variability if not the exact values of the different variables. Such validation is needed before using the model to forecast future scenarios in order to quantify and attribute the sources of uncertainty in such simulations.

Validation of complex ecosystem models is a non-trivial task. The first limitation is data availability: validating a complex ecosystem model on a large domain (like the North-Western European Shelf) requires a set of seasonal vertically resolved profiles of physical, chemical and biological variables covering the geographical extent of the whole domain. These datasets should cover an annual cycle to check the ability of the model to reproduce seasonal dynamics, several years to assess the reproduction of interannual variability and decadal scales to assess the presence of long term trends. Unfortunately no dataset meets all of these criteria, with a general trade-off between frequency and spatial coverage, while long term data is extremely rare. Merging the databases from different sampling programmes is not necessarily straightforward because of the mismatch in the type of variable measured, the analytical methods used and observational accuracy.

A second important limit is the spatial and temporal scale mismatch. Observed data are representative of a portion of water surrounding the few litres sampled whose dimension depends on the characteristic length scale of the local turbulent process. Oceanic models have a much more coarse spatial resolution and their output usually consists of temporal averages at daily time scale or longer.

A third issue, specific for the carbonate system, is the potential for mismatch between the generally accepted theoretical derivations of the carbonate system as used in models (e.g. Robbins et al. (2010)) and 'over-constrained' observational data sets. Four variables of the carbonate system are determinable in natural systems: DIC, TA, $\mathrm{pH}$ and $\mathrm{pCO}_{2}$. Theoretically, knowledge of any pair allows the derivation of the other members. However over-constrained carbonate system data sets have shown significant discrepancies when observed values have been compared with derived values calculated from a subset of the measured variables (Dickson and Millero, 1987; Hoppe et al., 2010; McElligott et al., 1998; Millero et al., 2002). Consequently, for example, pH derived from observed DIC and TA may differ significantly from directly observed $\mathrm{pH}$. The reason for this mismatch is undefined, potentially residing on the theoretical calculations of the equilibrium constants, observational inaccuracy or a conceptual understanding, in particular of alkalinity (Kim and Lee, 2009). This places limitations on the skill achievable by a model. The model system uses DIC and TA as its 'master' carbonate system variables; these are the only two available for dynamic models. The pair of master variables determines the minimum uncertainty achievable in the estimate of the derived carbonate system variables. With this choice, the uncertainty in $\mathrm{pH}$ and $\mathrm{pCO}_{2}$ estimates will be larger than with other pairs (Millero et al., 1993), while estimates of carbonate ion concentration (and then saturation state) will be more precise (Dickson, 2010).

In this work, we assess the skill of an improved version of the coupled hydrodynamic-ecosystem-carbonate system model POLCOMS-ERSEM (Blackford et al., 2004; Holt and James, 2001) in comparison to the CANOBA dataset (Thomas et al., 2004) which provides a seasonally, spatially and vertically resolved data set of the key carbonate system variables over one annual cycle.

Initially we analyse the consistency of the observed carbonate system with theoretical derivations of the carbonate system. This provides an estimate of the observational uncertainty and the limitations on model accuracy. Secondly, an improved dynamic alkalinity module is presented. Compared to earlier versions (Blackford and Gilbert, 2007), riverine alkalinity is now explicitly taken into account as well as the influence of ERSEM's biological processes on alkalinity. The new model is used to simulate the North-Western European Shelf over the period 2001-2002, concurrent with observations. The validation of the main biogeochemical variables is shown, with a particular focus on the carbonate system. The error in the modelled carbonate system is analysed where possible identifying the processes responsible for the inaccuracy. Finally some suggestions are provided for further model improvement and on how to reduce the uncertainty in the carbonate system, in particular when projecting the state of the carbonate system under future climate scenarios.

\section{Materials and methods}

\subsection{Data source, analysis and uncertainty}

The CANOBA project (CArbon and nutrient cycling in the NOrth Sea and the BAltic Sea) provided a comprehensive dataset ideal for 3D model validation over a seasonal cycle. It includes vertically resolved measures of physical (Temperature, Salinity) and chemical (Nutrients, dissolved oxygen, DIC, TA and $\mathrm{pH}$ ) variables repeated seasonally in a set of stations spread over the entire North Sea from summer 2001 to spring 2002. Partial pressure of $\mathrm{CO}_{2}$ has been measured with an underway system sampling water every minute during all four cruises. The uncertainty associated with the carbonate system parameter measurements is significantly lower than $0.5 \%\left(\varepsilon_{\mathrm{DIC}}=3 \mathrm{mmol} \mathrm{kg}{ }^{-1}, \varepsilon_{\mathrm{TA}}=1.5 \mu \mathrm{mol} \mathrm{kg}{ }^{-1}\right.$, $\varepsilon_{\mathrm{pCO} 2}=1 \mu \mathrm{atm}$ (Thomas et al., 2007).

To assess the magnitude of the discrepancies between the CANOBA dataset and theoretical calculations, $\mathrm{pH}$ and $\mathrm{pCO}_{2}$ have been calculated from the observed TA and DIC and compared with the observed value: this also provides a reference value for the model validation metrics. Additionally, the sensitivity of the derived variables to DIC and TA has been tested by analysing how the calculated $\mathrm{pH}$ and $\mathrm{pCO}_{2}$ vary in response to changes in DIC or TA starting from a reference point $\left(\mathrm{T}=15^{\circ} \mathrm{C}, \mathrm{S}=35 \mathrm{PSU}, \mathrm{DIC}=2100 \mu \mathrm{mol} \mathrm{kg}{ }^{-1}\right.$, $\left.\mathrm{TA}=2350 \mu \mathrm{mol} \mathrm{kg}^{-1}\right)$. This provides a useful insight to interpret the model validation.

All the calculations to solve the carbonate system from observed data have been made using the CO2sys software (Lewis and Wallace, 1998), following OCMIP recommendations for the set of constants, i.e. using the Weiss (1974) formulation of Henry's constant for $\mathrm{CO}_{2}$, the dissociation constants for carbonic acid defined by Millero (1995) using the refit of Mehrbach et al. (1973), and the borate dissociation constant from Millero (1995) using data from Dickson (1990). This is consistent with the scheme used within the dynamic model, except that here $\mathrm{pH}$ is expressed in the total scale for consistency with the dataset.

\subsection{Model description}

The model used is the coupled hydrodynamic-ecosystem model POLCOMS-ERSEM.

POLCOMS is a 3D baroclinic circulation model (Holt and James, 2001; Proctor and James, 1996). It is a primitive equation finite difference model using the "Piecewise Parabolic Method" advection scheme and the Mellor-Yamada level 2.5 turbulence closure to calculate viscosity and diffusivities. The model domain (Fig. 1) spans from $40^{\circ} \mathrm{N}$ to $65^{\circ} \mathrm{N}$ and from $20^{\circ} \mathrm{W}$ to $13^{\circ} \mathrm{E}$, with a horizontal resolution of approximately $12 \mathrm{~km}$ and depth resolved into $42 \mathrm{~s}$-coordinate layers. The model is forced by ERA40 meteorological data, and the model uses simulations from a 1 degree global ocean reanalysis (Smith and Haines, 2009) as boundary conditions. See Holt et al. (2009) and Wakelin et al. (2009) for further details of this configuration and its forcing. Light 
attenuation by non-biotic components is simulated as in Wakelin et al. (in press) by forcing the related attenuation coefficient with a climatology of the Inherent Optical Properties derived from satellite data (1998-2007 from the Sea-viewing Wide Field-of-view Sensor Project - SeaWiFS) using the algorithm developed by Smyth et al. (2006).

ERSEM is a coupled pelagic-benthic ecosystem model, focussed on the lower trophic levels (Baretta et al., 1995; Blackford et al., 2004). It is one of the more detailed marine biogeochemical models (Fig. 2) and it includes the main macronutrients (nitrogen, phosphate and silica), 4 phytoplankton Functional Types (PFTs), 3 zoo-PFTs, 3 bacteriaPFTs ( 1 pelagic and 2 benthic) and 3 zoobenthic groups. Carbon and nutrient dynamics are fully decoupled, allowing the simulation of luxury uptake and nutrient limitation within phytoplankton and consequently a more realistic simulation of phytoplankton physiology. The parameter set is defined by Blackford et al. (2004), except for a lower maximum $\mathrm{Chl}: \mathrm{C}$ ratio set to 0.035 according to the mean range of variation observed by Geider et al. (1997). The ecological model is initialised with homogeneous initial values corresponding to the average bulk properties of the shelf and spun up for five years. Input from rivers and from the Baltic Sea is explicitly accounted, updating at every timestep the height, the salinity and the concentration of nutrients, DIC and TA of all s-layers of the receiving cell following a simple mass balance.

Riverine nutrient loads are from Lenhart et al. (2010), while the Baltic inflow is treated crudely as an inflow source using a mean annual cycle of depth averaged transport, salinity and nutrients. Flow and salinity are derived from the Danish Hydrographic Institute DYNOCS experiment (more detail in Holt and James, 2001). Nutrient concentration has been calculated imposing a sinusoidal cycle between the winter and summer value of depth averaged nutrients measured in Arkona Bay by Andersson and Andersson (2006). DIC and TA of Baltic waters have been calculated from salinity using Thomas and Schneider (Thomas and Schneider, 1999) and Hjalmarsson et al. (Hjalmarsson et al., 2008).

ERSEM is coupled to a carbonate system module that calculates all the carbonate system variables using the HALTAFALL speciation code (Ingri et al., 1967) starting from DIC and TA (Blackford and Gilbert, 2007). In the original version, TA was calculated using two linear regressions one with positive slope for salinity higher than 34.65 (derived from Norwegian Sea data, Bellerby et al., 2005) and one with negative slope to take account of riverine discharge of alkalinity (derived from Dutch coast data, Borges and Frankignoulle, 1999). This parameterisation is crude as it treats the entire coastal area using a single statistical relation derived from an area influenced by a river

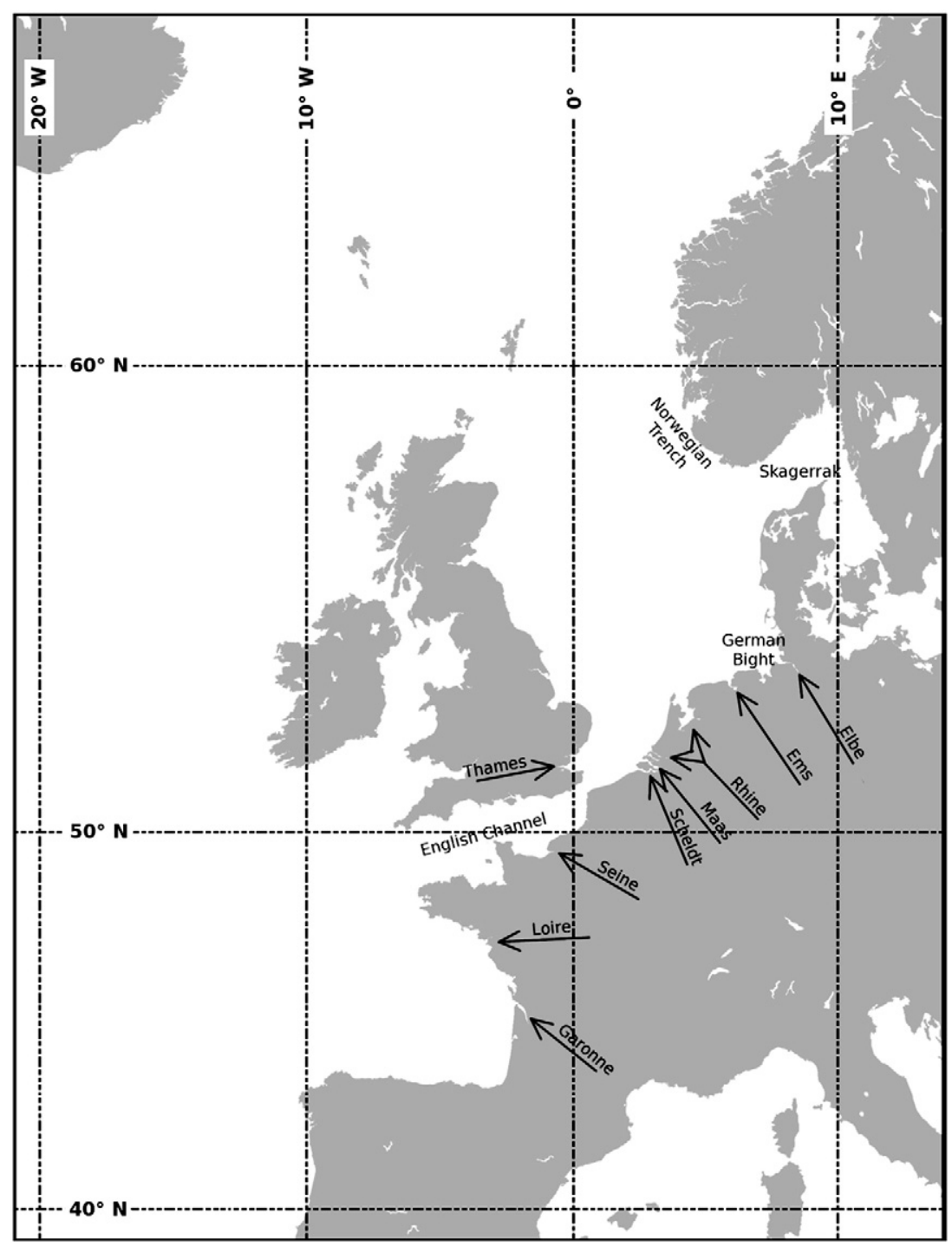

Fig. 1. Map of the area studied with major rivers and place-names. 


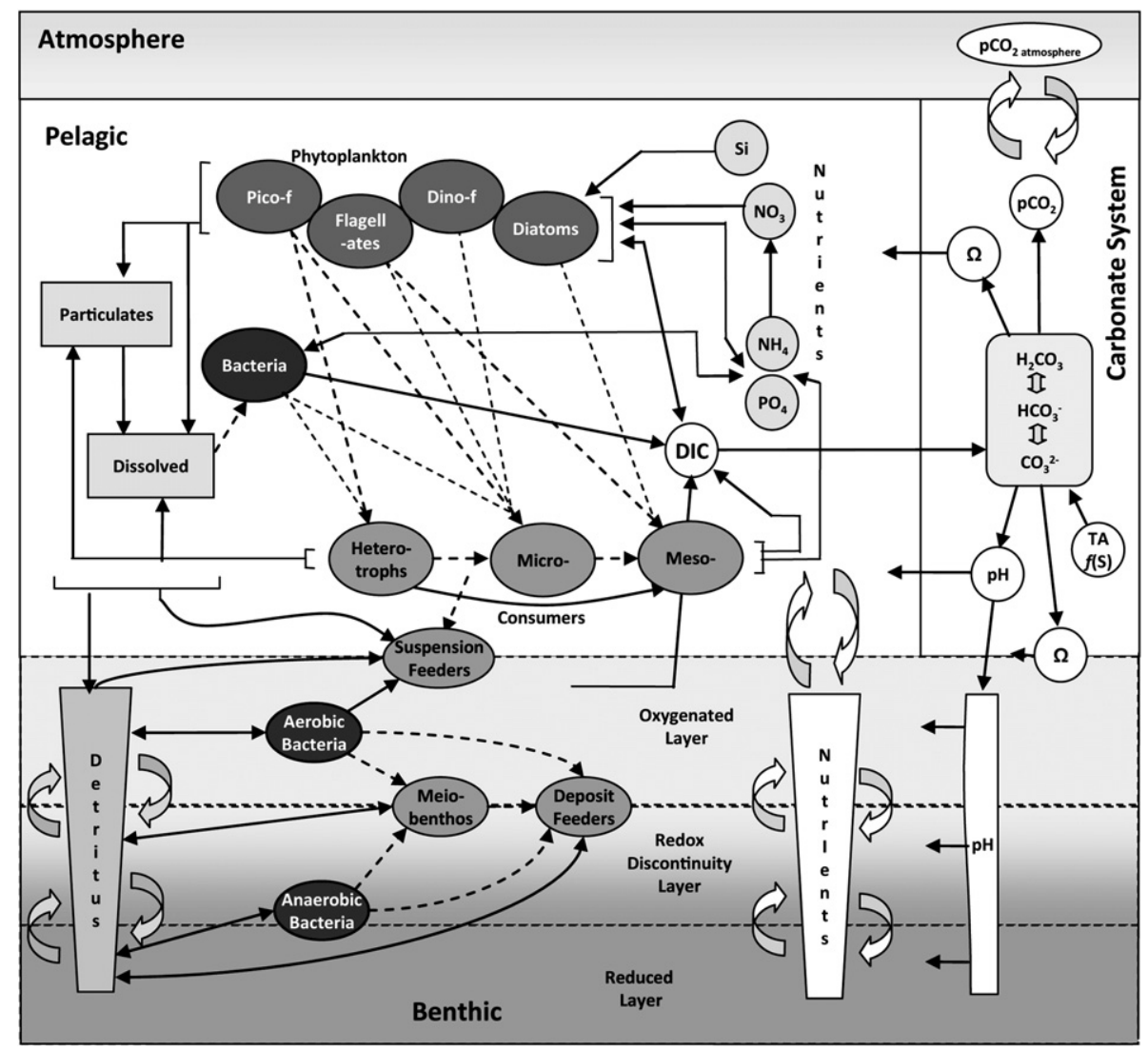

Fig. 2. Conceptual diagram of ERSEM.

with high alkalinity. Furthermore it does not consider how changes in nutrient concentration affect TA, underestimating the variability of the latter. Consequently, TA has been decomposed into two components:

$$
\begin{aligned}
& T A=T A_{\text {dia }}+T A_{\text {pro }} \\
& T A_{\text {dia }}=51.24 S+520.1 \\
& \frac{d T A_{\text {pro }}}{d t}=\frac{1}{\rho}\left(\sum_{\text {bio }} \frac{d\left(\mathrm{NH}_{4}\right)}{d t}-\sum_{\text {bio }} \frac{d\left(\mathrm{NO}_{3}\right)}{d t}-\sum_{\text {bio }} \frac{d\left(\mathrm{PO}_{4}\right)}{d t}\right) \\
& +\frac{1}{\rho} \sum_{\text {riv }} \frac{Q}{V}\left(T A_{\text {riv }}-520.1\right)
\end{aligned}
$$

where TA is the Total Alkalinity, $\mathrm{TA}_{\mathrm{dia}}$ is a diagnostic component calculated from salinity $(S), \mathrm{TA}_{\text {pro }}$ is the prognostic component, $\rho$ is the seawater density, the sums with bio as index are the sum of the change of nutrient concentrations due to the biochemical processes, the sum over the index riv is the sum of the contribution of all the rivers discharging in that grid cell of volume $\mathrm{V}, \mathrm{Q}$ is the river flow and $\mathrm{TA}_{\text {riv }}$ is the TA from the river.

The diagnostic component represents the oceanic contribution calculated using the standard regression between TA and salinity for the Atlantic Ocean (Millero et al., 1998). The second component is a prognostic variable that is fully advected and diffused by the circulation model. It simulates the variability of TA due to all the biogeochemical processes influencing nutrients (e.g. nutrient uptake/mineralisation, nitrification or denitrification) and also due to riverine input. This part needs to keep track only of nutrient concentration, as the contribution of the total initial nutrient concentration to TA is already accounted for in the diagnostic alkalinity and the contribution of nutrient inflow is included in the riverine alkalinity. For this reason, $\mathrm{TA}_{\text {pro }}$ is initialised to zero and can have negative values (e.g. in offshore areas during a bloom). As for nutrients, the impact of TA from rivers is calculated using a simple mass-balance, diluting the total mass of TA discharged by the river in the entire water column of the receiving cell. As the diagnostic component already considers a background TA for freshwater $\left(=520.1 \mu \mathrm{mol} \mathrm{kg}{ }^{-1}\right)$ this value has been subtracted to all riverine TA.

Due to lack of data describing riverine TA, the end member approach has been used to infer riverine concentration from observed data, as in Hjalmarsson et al. (2008). The stations nearest to the coast in the CANOBA dataset have been grouped on the basis of their geographical distribution: for each of this group the linear correlation between TA and salinity has been studied and the riverine TA concentration has been estimated by extrapolating this linear regression to a value of salinity equal to 0 . Where observed data are available for particular rivers they have been used instead of the estimated values (Table 1). The low correlation coefficient obtained for the eastern Coast of UK and the English Channel is mostly due to the fact that in this area the rivers are generally smaller (with the exception of Thames) hence their influence is restricted to the more coastal area not captured by the CANOBA dataset.

For all the rivers included in the model but not discharging into the North Sea a constant concentration of $2000 \mu \mathrm{mol} \mathrm{kg}{ }^{-1}$ has been assumed, being the average of the riverine TA estimated. This last assumption is certainly over-simplistic and needs refining, but it does not significantly influence the validation of the model presented in this paper, as the observed data used pertain only to the North Sea. Furthermore, except for the Seine, the larger of these rivers (e.g. west coast of France) are distant from the North Sea, and so unlikely to influence the results on the seasonal to annual time scales considered here.

The set of carbonate system constants used is the one adopted in the OCMIP process, and is detailed in the previous section.

\subsection{Validation approach}

Previous papers have evaluated this model system with respect to hydrodynamics, lower trophic dynamics, the continuous plankton 
Table 1

Riverine total alkalinity for the different coasts of the North Sea as estimated from the extrapolation of the regression with salinity data. $\mathrm{R}^{2}$ is the coefficient of determination of the correlation between TA and salinity in the different coastal stations. Where available, the annual mean from observed data has been used.

\begin{tabular}{lll}
\hline Area & Total alkalinity $\left[\mu \mathrm{mol} \mathrm{kg}^{-1}\right]$ & $\mathrm{R}^{2}$ \\
\hline English Channel & 1887 & 0.18 \\
East UK coast & 1358 & 0.17 \\
Western Norwegian coast & 1612 & 0.88 \\
Skagerrak coast & 1652 & 0.85 \\
German Bight & 2054 & 0.42 \\
Belgium and Dutch coast & 3181 & 0.50 \\
Elbe $^{\mathrm{a}}$ & 2231 & - \\
Ems $^{\mathrm{a}}$ & 2562 & - \\
Meuse $^{\mathrm{a}}$ & 2580 & - \\
Rhine $^{\mathrm{a}}$ & 2580 & - \\
Scheldt $^{\mathrm{a}}$ & 3832 & - \\
\hline
\end{tabular}

a Pätsch and Lenhart (2004)

recorder data set and satellite data (Allen et al., 2007; Holt et al., 2005; Lewis et al., 2006; Shutler et al., 2011) The validation approach used here is the classical univariate "like-with-like" comparison: each observed value has been compared to the daily average simulated by the model in the closest grid cell and then a range of metrics has been calculated to evaluate comprehensively the performance of the model for each variable considered. This is a harsh test of the model, excluding any aggregation of data (beyond the grid scale) and is sensitive to relatively minor spatial and temporal mismatches between model and observations.

Measurements of DIC and pH have been converted to the model units, i.e. $\mathrm{mmol} \mathrm{m}^{-3}$ and SWS scale units using CO2SYS (Lewis and Wallace, 1998).

The evaluation metrics used are the following:

- the root mean squared error (RMSE) and the root mean squared error normalised by the mean value of the observed data expressed as percentage (\%RMSE).

- the model bias (Bias) and the model bias normalised by the mean of observed values expressed as percentage (\%Bias), to evaluate the degree of systematic overestimation (or underestimation) made by the model

- the cost function (CF) as defined by OSPAR (1996), that assesses the mean absolute error in comparison with the standard deviation of the observed data;

- the coefficient of determination (R2), which measures the strength of the correlation between simulated values and observations;

- the Nash Sutcliff Model Efficiency (Nash and Sutcliffe, 1970), conceived to test model ability to reproduce the magnitude and timing of peaks.

The equations for all these metrics are provided in Appendix A.1.

As $\mathrm{pCO}_{2}$ is measured by underway techniques with a much finer spatial resolution than the model grid, all these data have been regridded and averaged onto the model grid.

Simulated $\mathrm{pH}$ and $\mathrm{pCO}_{2}$ have also been validated against the homologous values calculated from observed DIC and TA. In such a way it is possible to disentangle the impact of the propagation of the error on the master variables from the error linked to the uncertainty in the carbonate system.

\subsection{Analysis of model uncertainty}

In this work, the analysis of model uncertainty has focussed on the causes of uncertainty in the simulation of $\mathrm{pH}$ : this has been defined as the error in $\mathrm{pH}$ due to the propagation of the errors from the master variables DIC and TA. The relative errors on DIC and TA have been averaged over depth for each season and location, and then their propagation has been calculated using the equations of the linear correlation emerging from the sensitivity analysis (see Section 3.1). In such a way it is possible to evaluate the total error on $\mathrm{pH}$ due to the errors in the master variables and to identify which variable is contributing the most to this error. From the analysis of the spatial and temporal variability of this information, it is also possible to infer what are the major processes driving the $\mathrm{pH}$ uncertainty.

\section{Results}

\subsection{Data analysis}

As stated by Millero et al. (1993), deriving $\mathrm{pH}$ and $\mathrm{pCO}_{2}$ from DIC and TA should lead to an error on the estimates within respectively $0.0062 \mathrm{pH}$ units and $5.7 \mu \mathrm{atm}$ while the precision associated with the measurement of those variables is assumed to be $0.003 \mathrm{pH}$ unit and $1 \mu \mathrm{atm}$ (Dickson et al., 2007).

The comparison between observed $\mathrm{pH}$ and the $\mathrm{pH}$ calculated from observed DIC and TA (Table 2) evidences a bias of approximately $0.004 \mathrm{pH}$ units and a Root Mean Squared Error (RMSE) of $0.021 \mathrm{pH}$ units, the latter corresponding to approximately 7 times the error associated with the measurement, and more than 3 times the error expected from calculation. The linear correlation between observed and calculated values has a slope equal to 0.985 indicating that the software used (CO2sys) does not make systematic errors, but the correlation coefficient is barely adequate $(R 2=0.49)$. Unfortunately direct measures of $\mathrm{pH}$ have been taken only in one cruise (February-March 2002), and hence the estimate of the uncertainty can be biassed as the entire seasonal cycle is not represented. Similar results were observed when comparing measured and calculated $\mathrm{pCO}_{2}$ (Table 2), with a bias of about $-1.0 \mu \mathrm{atm}$ and a RMSE of $25.8 \mu \mathrm{atm}, 25$ times the expected precision of the measurements and 4 times the error expected from calculation, however the correlation is much stronger $(\mathrm{R} 2=0.76)$.

Fig. 3 shows the sensitivity of $\mathrm{pH}$ and $\mathrm{pCO}_{2}$ relative to change in DIC or TA: $\mathrm{pH}$ responds almost linearly with a slope lower than 1 , evidencing that relative changes in $\mathrm{pH}$ units tend to be lower than the ones in the master variables. However, as $\mathrm{pH}$ is a logarithmic scale, this corresponds to an exponentially increasing difference in the hydrogen ion concentration (organisms experience ' $\mathrm{H}^{+}$' not $\mathrm{pH}$ ). Similarly, $\mathrm{pCO}_{2}$ exhibits a high sensitivity, with an exponential response to changes in DIC and TA.

This sensitivity analysis allows us to derive the equations to calculate how relative error in TA or DIC $(\Delta \% \mathrm{TA}, \Delta \% \mathrm{DIC})$ propagates in $\mathrm{pH}$ estimates.

$$
\begin{aligned}
& \Delta p H=-0.042 \Delta \% D I C \\
& \Delta p H=0.045 \Delta \% T A .
\end{aligned}
$$

These have been used to estimate how much of the $\mathrm{pH}$ uncertainty is due to errors in DIC or TA (see Section 3.4). The linear correlation between changes in $\mathrm{pH}$ and changes in the master variables holds in the entire domain of the observed TA and DIC $\left(R^{2}>0.9\right)$ and the difference in the values of the coefficients is small for the purpose of this analysis.

Fig. 3 also shows how TA and DIC have an antagonistic impact on $\mathrm{pH}$ and $\mathrm{pCO}_{2}$ : errors with same sign in those variables tend to compensate when the carbonate system is resolved.

Table 2

Uncertainty of the carbonate system in the CANOBA dataset. Observed $\mathrm{pH}$ and $\mathrm{pCO}_{2}$ have been compared with the values calculated from observed DIC and TA using the standard software $\mathrm{CO} 2$ sys. The precision of the observation and expected error from the calculation is also reported for comparison.

\begin{tabular}{lcclll}
\hline & RMSE & Bias & R2 & Error from calculation ${ }^{\mathrm{a}}$ & precision \\
\hline $\mathrm{pH}$ & 0.021 & 0.004 & 0.49 & 0.006 & 0.003 \\
$\mathrm{pCO}_{2}$ & 25.8 & -0.96 & 0.76 & 5.7 & 1 \\
\hline
\end{tabular}

a Millero et al. (1993). 

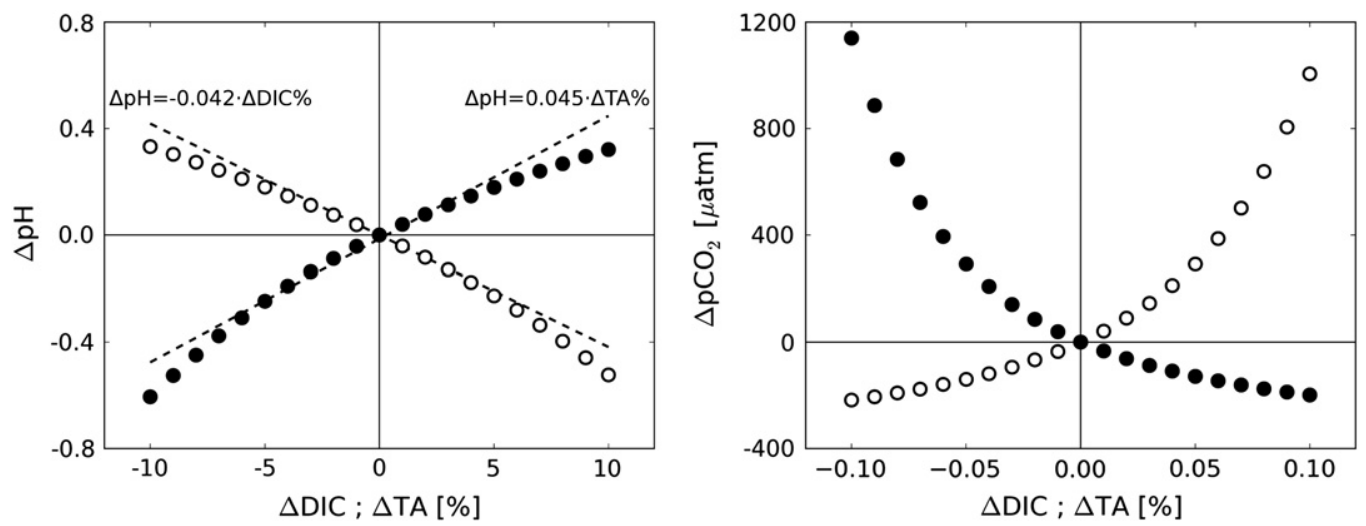

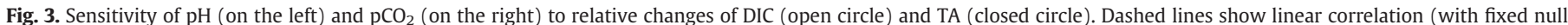
intercept) between relative error in DIC (or TA) and error in $\mathrm{pH}$.

\subsection{Model results}

The model demonstrates significant heterogeneity in the carbonate system across the entire domain. Fig. 4 shows the seasonal average of surface $\mathrm{pH}$ : the seasonal pattern emerges clearly, with generally higher $\mathrm{pH}$ during the productive seasons (spring and summer). Other general patterns are the higher $\mathrm{pH}$ along the Belgian, Dutch and German coast due to high alkalinity discharge from regional rivers (e.g. the Scheldt, Rhine and Elbe) and lower pH on shelf compared to off shelf (mostly due to higher DIC) and on the Norwegian trench (because of the strong influence of the low alkalinity waters coming from the Baltic). Thermal stratification in central and northern North Sea during the warm months separates the water column into two environments: the surface area where DIC drawdown due to primary production leads to a rise of

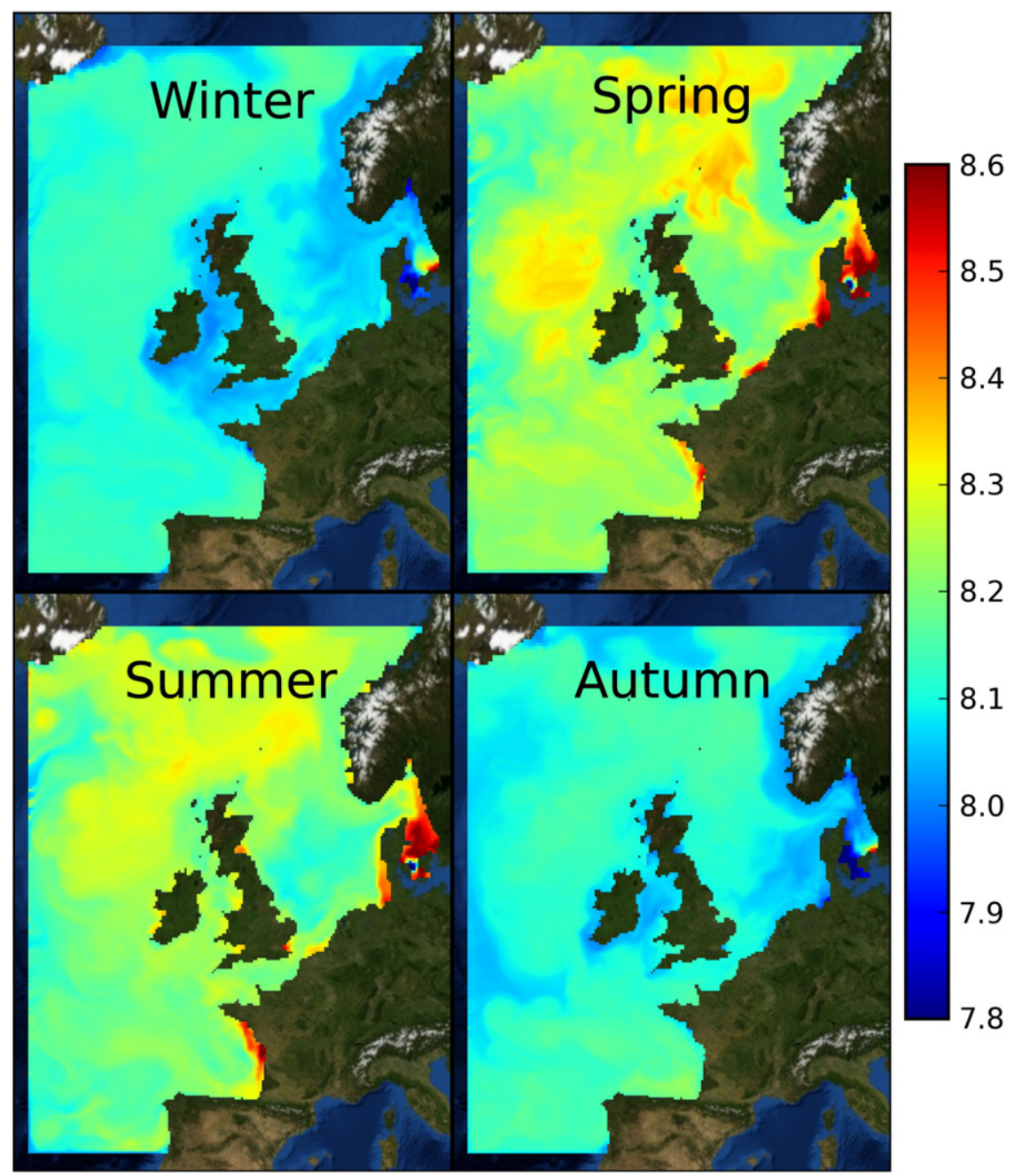

Fig. 4. Seasonal average of simulated surface $\mathrm{pH}$. 
$\mathrm{pH}$, and the bottom area where the community respiration dominates any residual photosynthetic activity and together with benthic fluxes of DIC leads to a decrease of pH (Fig. 5)

On top of these characteristic patterns, there is a significant variability on shorter scales (both spatial and temporal) linked to hydrodynamic features like tides, eddies, fluctuations of river discharge, and weather variability (not shown). Biological drawdown of DIC due to short phytoplankton blooms also plays an important role in determining $\mathrm{pH}$ variability, together with nutrient dynamics along the southern coast of the North Sea: in this area the range of variation of nitrate is close to $30 \mathrm{mmol} \mathrm{m}^{-3}$ and up to $100 \mathrm{mmol} \mathrm{m}^{-3}$ close to river mouths. This leads to a relative increase of TA of about 1 to $4 \%$ and, using the linear equation derived in Section 3.1, to a variation of $\mathrm{pH}$ ranging from 0.04 to $0.15 \mathrm{pH}$ units.

\subsection{Model validation}

The results of the validation are summarized in Table 3 and Fig. 6 . The temporal and spatial distribution of the errors for each variable is shown in a series of maps in the supplementary information (Fig. S1S8). As already observed by Allen et al. (2007), each metric provides a different insight on the ability of the model to simulate the dynamics of the North Sea ecosystem, nevertheless some general conclusions can be drawn.

Compared with the other variables considered here, the model is able to represent very well the physical variables of the North Sea, either in terms of bulk properties (RMSE, bias and cost function), variability (correlation) and events (ME). The model shows difficulties in simulating the low salinity areas (Fig. 6), particularly in the southern coast (Belgium, Netherlands, Germany) where the major rivers discharge. Simulations of nitrate and phosphate show good results with a consistent but yet acceptable overestimation of both nutrients, and reasonable correlation and efficiency. Fig. 7 shows how the depth-averaged error of these variables varies spatially in summer and winter: the larger errors occur along the southern coast where the influence of the river loads is maximum. During summer a difference between the RMSE calculated using only the uppermost data for each station (RMSEsur) and the one calculated from the deepest data (RMSEbot) is observed with the latter highest.

Silicate on the contrary is considerably underestimated and poorly correlated with observed values.

Regarding the carbonate system, the master variables, DIC and TA are both well simulated in terms of average values (almost a null bias) but the variability is not represented equally well; correlation

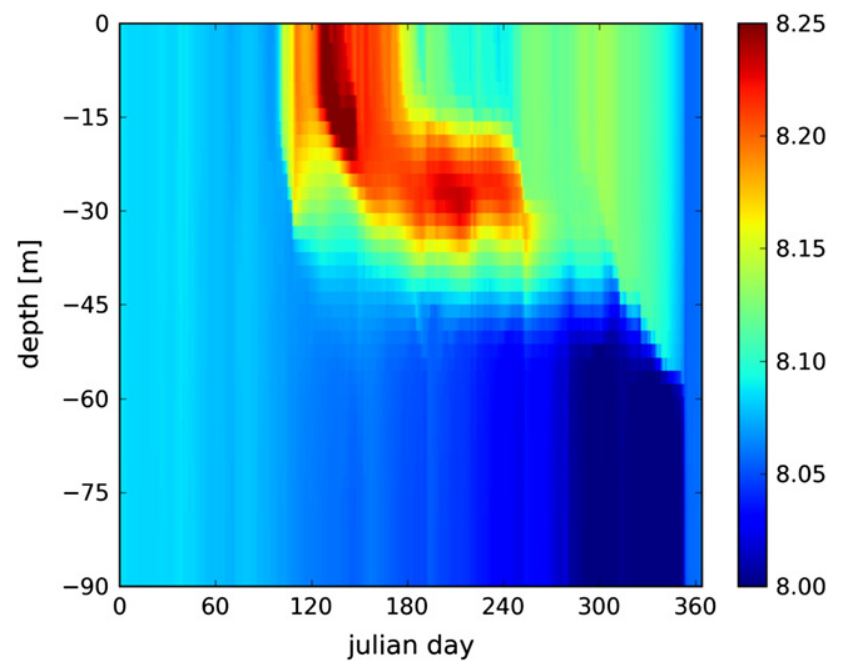

Fig. 5. Hoevmöller diagram of simulated $\mathrm{pH}$ for a location in the central North Sea (lat $56.5^{\circ} \mathrm{N}$ lon $2^{\circ} \mathrm{E}$.
Table 3

Values of the validation metrics for all the variables. Values between parentheses refer to the old parameterization of TA (see Blackford and Gilbert (2007)). Reference value of the perfect model for each metrics is provided in the first row.

\begin{tabular}{llllllll}
\hline & RMSE & \%RMSE & Bias & \%Bias & CF & R2 & ME \\
\hline Ref. value & 0.0 & 0.0 & 0.0 & 0.0 & 0.0 & 1.0 & 1.0 \\
Salinity & 0.75 & 2.17 & 0.07 & 0.20 & 0.36 & 0.58 & 0.55 \\
Temperature & 1.07 & 11.20 & 0.31 & 3.23 & 0.25 & 0.89 & 0.88 \\
PO4 & 0.20 & 42.23 & -0.09 & -17.81 & 0.53 & 0.62 & 0.49 \\
$\mathrm{NO} 3$ & 4.13 & 64.22 & -1.65 & -25.57 & 0.53 & 0.52 & 0.39 \\
$\mathrm{Si}$ & 2.35 & 72.66 & 1.17 & 36.29 & 0.73 & 0.30 & -0.08 \\
$\mathrm{DIC}$ & 35.63 & 1.64 & 5.63 & 0.26 & 0.64 & 0.50 & 0.28 \\
& $(41.66)$ & $(1.92)$ & $(-0.98)$ & $(-0.04)$ & $(0.69)$ & $(0.41)$ & $(0.02)$ \\
$\mathrm{TA}$ & 22.45 & 0.97 & -5.09 & -0.22 & 0.61 & 0.25 & 0.26 \\
& $(49.61)$ & $(2.15)$ & $(-11.76)$ & $(-0.51)$ & $(0.93)$ & $(0.00)$ & $(-2.62)$ \\
$\mathrm{PCO}_{2}$ & 64.65 & 19.09 & 15.34 & 4.53 & 1.04 & 0.22 & -1.01 \\
& $(64.33)$ & $(19.00)$ & $(31.66)$ & $(9.35)$ & $(1.01)$ & $(0.30)$ & $(-0.99)$ \\
pH & 0.04 & 0.52 & -0.0008 & -0.006 & 1.53 & 0.06 & -2.80 \\
$\mathrm{Calc}^{\text {a }} \mathrm{PCO}_{2}$ & $(0.05)$ & $(0.61)$ & $(-0.003)$ & $(-0.34)$ & $(1.82)$ & $(0.14)$ & $(-4.34)$ \\
$\mathrm{Calc}^{\mathrm{a}} \mathrm{pH}$ & $(62.53$ & 15.68 & 20.36 & 5.55 & 0.85 & 0.31 & -0.24 \\
& 0.07 & $(16.92)$ & $(15.16)$ & $(4.13)$ & $(0.92)$ & $(0.30)$ & $(-0.45)$ \\
& $(0.08)$ & $(0.96)$ & $(-0.03$ & -0.35 & 0.91 & 0.34 & -0.47 \\
\hline
\end{tabular}

a Values calculated from observed DIC and TA using the software CO2sys.

has intermediate strength and the model exhibits a low efficiency, with DIC showing a better agreement with data than TA. Validation of the derived variables, $\mathrm{pCO}_{2}$ and $\mathrm{pH}$, is very poor, with very low correlation between model and data (although $\mathrm{pH}$ data are available only for the winter cruise - February 2002) and negative efficiency. Fig. 8 details the spatial pattern of error in $\mathrm{pCO}_{2}$ simulations indicating that the larger errors occur mostly in the Norwegian trench where $\mathrm{pCO}_{2}$ is overestimated over much of the year (except summer) and in the North Sea during the productive seasons: spring in the Northern North Sea and summer in the Southern North Sea. The error introduced by averaging observed data on the model grid is generally not significant. The variability of observed pCO2 inside a single cell is indeed significantly lower than the model error as evidenced by the statistics of the intra-cell standard deviation of observed pCO2 (mean $=3.1 \mu \mathrm{atm}$; median $=1.7 \mu \mathrm{atm}$; 95th percentile $=10.7, \mathrm{n}=3078$ ).

A small improvement in the validation of the variability of these variables is observed when they are compared to the values calculated from the observed DIC and TA (last two lines of Table 3). Correlation between simulated and recalculated $\mathrm{pH}$ significantly increases (from 0.06 to 0.33 ) evidencing the importance of having a full seasonal cycle of observations.

The model has been run also with the old alkalinity parameterisation in order to quantify the improvement of the changes proposed in this work. The results (reported between parentheses in Table 3) show a significant improvement in the simulation of TA, particularly in terms of variability explained (with the new model the correlation coefficient goes from 0 to 0.25 ) and ability on capturing events (positive ME). A small, less significant improvement in DIC is seen, possibly due to improved parameterisations of the $\mathrm{C}: \mathrm{Chl}$ ratio, alternatively following from the influence of alkalinity on $\mathrm{pCO}_{2}$ and the subsequent modification of air-sea exchange.

\subsection{Attribution of $\mathrm{pH}$ uncertainty}

Fig. 9 shows how the errors in TA and DIC contribute to $\mathrm{pH}$ uncertainty. The largest uncertainty in $\mathrm{pH}$ occurs during the productive seasons (spring and summer) and it is driven mostly by the DIC errors (majority of black circles) except in some coastal stations (e.g. close to the Elbe or the Rhine river mouth). During cold seasons the uncertainty of $\mathrm{pH}$ is generally low and equally driven by either of the master variable, although local larger uncertainties are still present along the coast due to high errors in TA. 

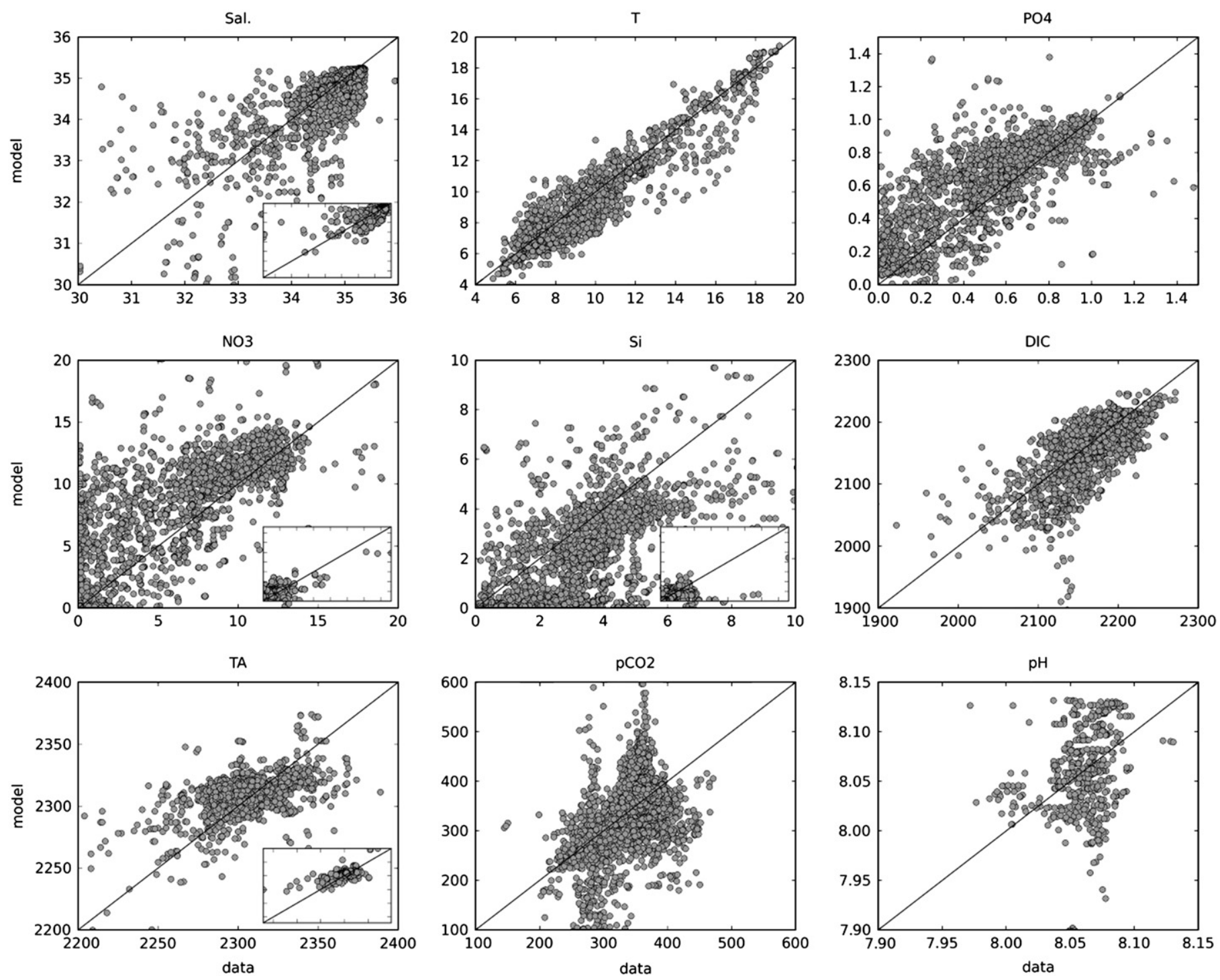

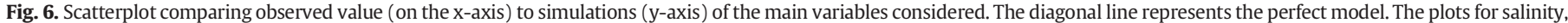
nitrate, silicate and TA have been zoomed to avoid scale problems linked to outliers. The small subplot in each of these panels shows the full range of model-data comparison.

\section{Discussion}

Shelf seas are known to be characterised by high variability in physical, chemical and biological compartments, and this work confirms that the same variability applies to the carbonate system. This is of particular interest in the context of $\mathrm{OA}$, where the predictive focus has been more on off-shelf averages over large domains. The model demonstrates that many diverse environments can be present, either constantly or seasonally, in the North Sea, and these could respond differently to OA. For example it can be hypothesised that the deep water of the central North Sea could reach a critical value of $\mathrm{pH}$ (or carbonate saturation state) earlier than other areas due to the combined effect of stratification and benthic fluxes in summer. On the contrary the southern coast could potentially be less affected by the increase in atmospheric $\mathrm{pCO}_{2}$ due to the high alkalinity riverine inputs which are the major driver for the carbonate system in that region. Gypens et al. (2011) evidenced how much riverine DIC and nutrients contribute to determine $\mathrm{pH}$ in the coastal areas: they estimated a maximum decrease of $\mathrm{pH}$ of about 0.2 depending on scenarios of river discharge, i.e. close to the forecasted decrease due to $\mathrm{OA}$ at the end of the century. Consequently, changes in river flow patterns due to climate change and in river concentrations due to change in land use and anthropogenic activities in the catchment will have a strong influence on the carbonate system in these areas, potentially masking or exacerbating the atmospheric effect (Borges and Gypens, 2010).

The model validation presented here confirms the robustness of POLCOMS-ERSEM in simulating the NW European Shelf ecosystem. The model captures most of the variability of the main physical variables and the most important macronutrients (nitrate and phosphate). However it exhibits some problems in representing the lower salinity areas, mostly because the spatial resolution is not adequate to resolve river plumes and the accuracy of the riverine forcing and Baltic fluxes is limited. The significant bias and RMSE in the nutrients may be reduced by improving initial conditions as well as boundary conditions, in particular riverine and Baltic fluxes that cause a consistent overestimation. Furthermore the larger error (mostly due to overestimation) in the bottom waters during summer suggests that the model underestimates the vertical mixing and/or overestimates the benthic fluxes of nutrients. A more detailed analysis shows that the high RMSE for nitrate and phosphate is also due to a mismatch in timing of the blooms (Butenschön, pers. comm.).

DIC and TA are generally well represented by the model. In particular, the new formulation for TA significantly improves the simulation of this variable but does not affect significantly the other variables of the carbonate system, except for a slight improvement 


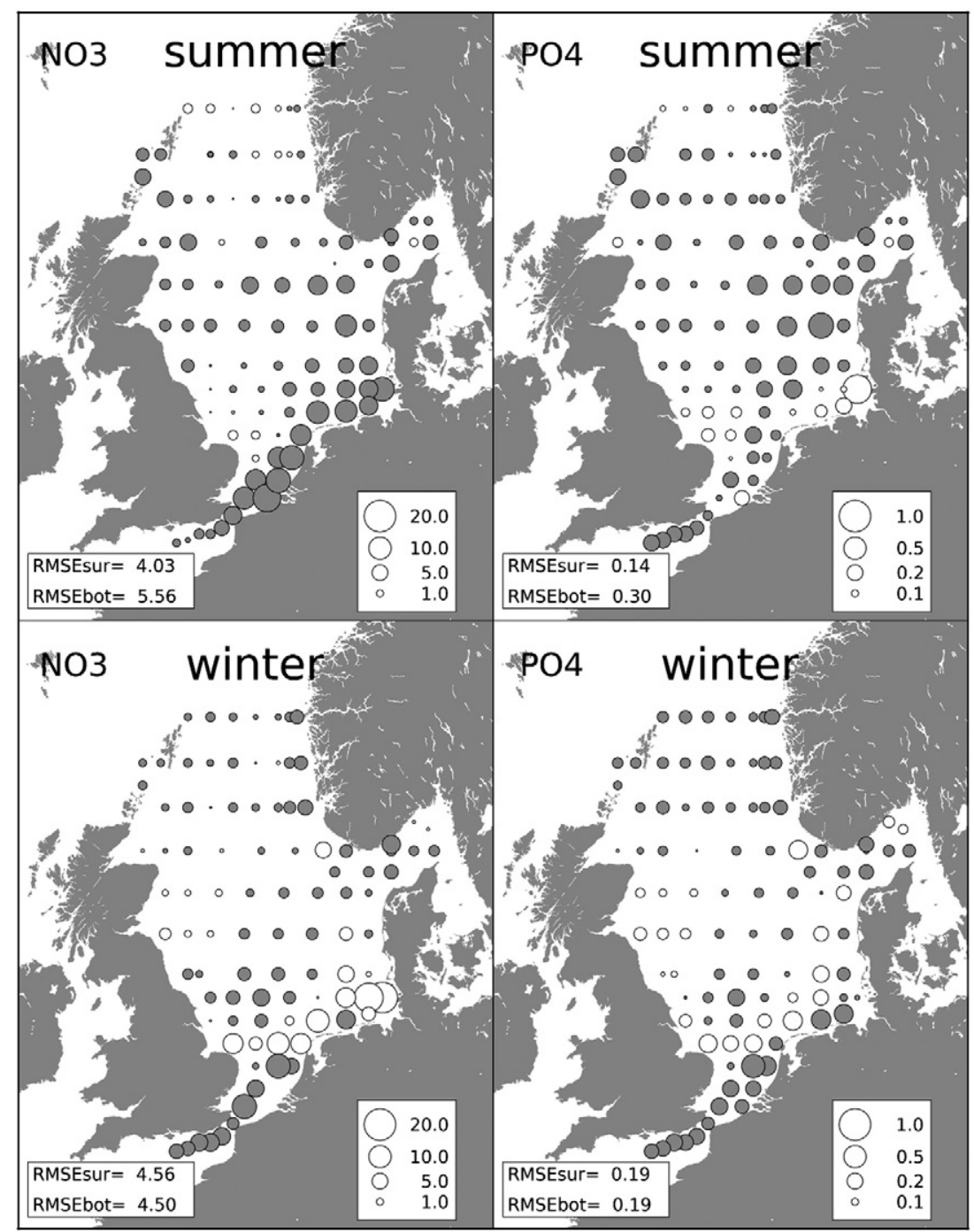

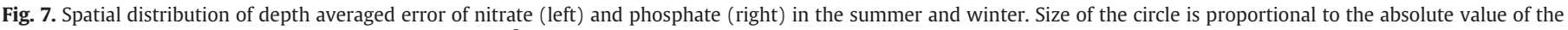

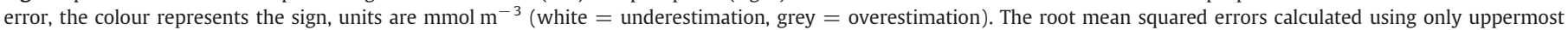
observed value (RMSEsur) and the deepest values (RMSEbot) for each sampling station are reported in the boxes on the bottom left corner of each plot.

of the description of DIC. This is possible, despite DIC not being directly dependent on TA, through a localised improvement of the $\mathrm{CO}_{2}$ airsea fluxes due to change in riverine alkalinity and consequently in coastal $\mathrm{pCO}_{2}$.

Deriving the open sea TA from salinity helps to constrain this variable and to avoid drift due to poorly resolved boundary and/or initial conditions. This has the drawback of a potentially large underestimation of TA in the coastal areas, where the linear correlation would lead to low value. To overcome this error, it is very important to simulate explicitly the riverine input of TA: in the southern coast of the North Sea the model estimates that $5-30 \%$ of the TA derives from rivers. The strong overestimation of salinity along the Dutch coast and in the Eastern English Channel does not impact significantly the estimates of TA: indeed in these areas TA is mostly underestimated and not strongly overestimated as one would expect given the consistent overestimation of 1 or more in salinity (see Fig. S2). This means that the end member approach used to derive riverine TA underestimates this variable and hence compensates for the error in salinity. Despite this error, this approach is still valuable as it allows a reasonable estimate of this boundary condition otherwise scarcely available, and it takes account the different catchments and hence better represents the impact of the variability of terrestrial processes on coastal carbonate chemistry. Accurate predictions of terrestrial processes and riverine run off are likely to be important when considering seasonal and interannual variability or long-term trends of DIC and TA in coastal regions (Raymond et al., 2008).

Another source of error is the lack of simulation of the benthic processes affecting alkalinity, such as sulphate reduction. Jørgensen et al. (1990) evidenced how only a small part (4-32\%) of the sulphate reduced in the sediment is permanently buried as pyrite, while the rest is reoxidized. Thomas et al. (2009) estimated that in the Wadden Sea sulphate reduction should generate between 12 and $26 \mathrm{Gmol} \mathrm{y}^{-1}$ of TA, of which only a small part would be definitively released to the water column. This source of uncertainty, despite being relevant particularly on the local scale, is of secondary importance in this study as the medium spatial resolution of the model is not able to resolve estuaries or tidal flats, and the riverine input, and associated uncertainty, is much more significant (e.g. the Elbe discharges about $50 \mathrm{Gmol} \mathrm{y}^{-1}$ ). Contribution of carbonate dissolution in the sediments to benthic TA fluxes is one order of magnitude lower. Suykens et al. (2011) estimated an average flux of $0.33 \mathrm{mmolCaCO}_{3} \mathrm{~m}^{-2} \mathrm{~d}^{-1}$ on the Celtic Sea shelf break: assuming similar value for the Wadden Sea, this would generate a flux about $1.2 \mathrm{Gmol} \mathrm{y}^{-1}$ of TA.

Despite the reasonable simulation of DIC and TA, all the validation metrics indicate that the simulation of $\mathrm{pH}$ and $\mathrm{pCO}_{2}$ is comparatively poor, particularly in representing the variability. To ensure that the 


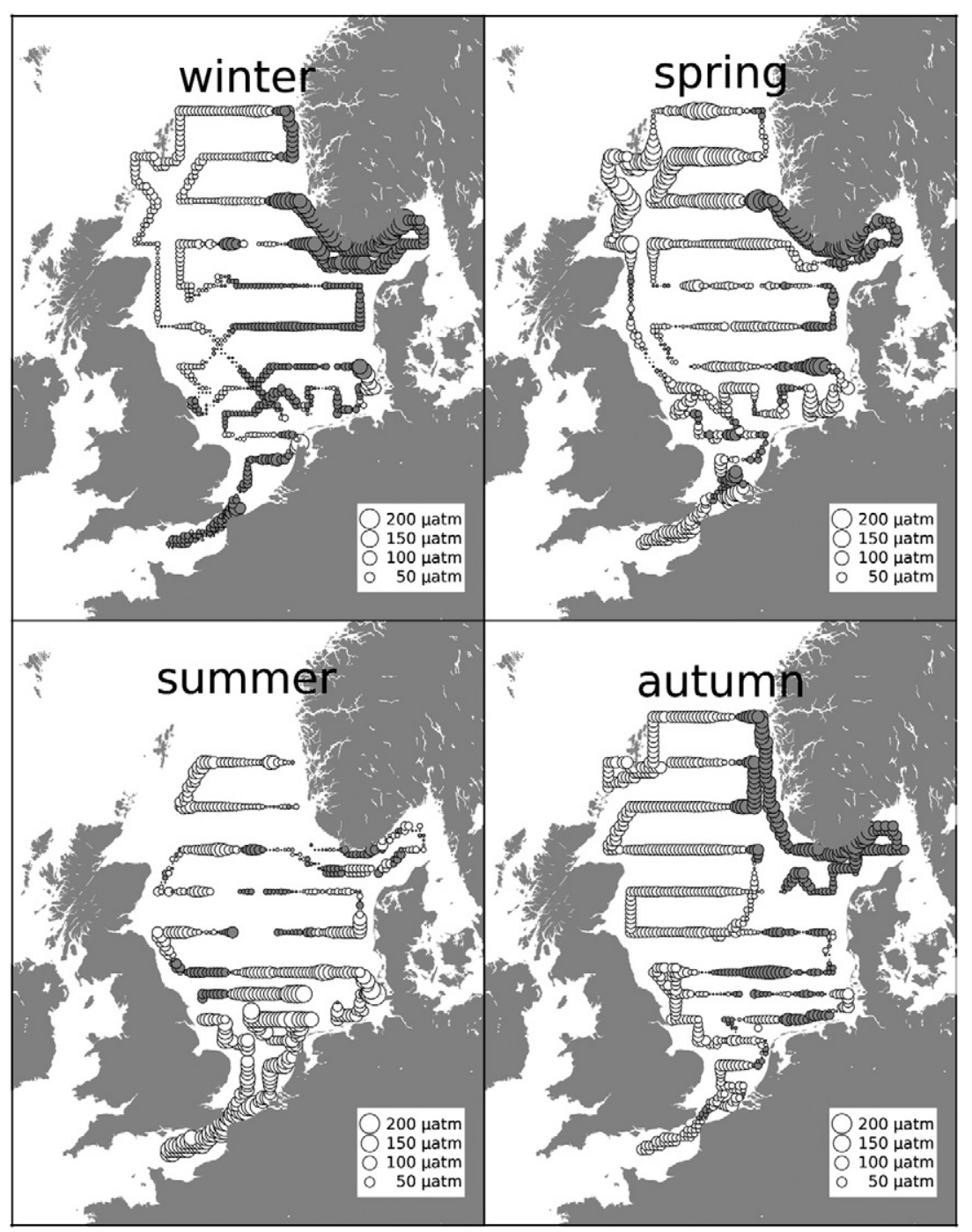

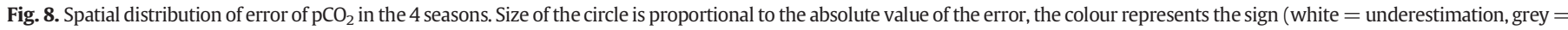
overestimation).

carbonate system submodule was performing adequately the model $\mathrm{pH}$ and $\mathrm{pCO}_{2}$ fields were compared with derivations using CO2sys software based on the same modelled fields of DIC and TA. An almost perfect match was found, with the difference due only to different numerical precision. Several aspects coincide to determine the quality of the validation. Firstly, the evaluation is strongly influenced by localised error in the master variables: for instance the scatterplot comparing $\mathrm{pCO}_{2}$ data (Fig. 6) and simulation shows two peaks of significant overestimation (exceeding 100\%). Both occur on the Norwegian coast and are due to low alkalinity values: this area is highly influenced by the freshwater coming from Norwegian rivers and fjords as well as the Baltic outflow hence an error in the estimates of TA discharged by these inputs has a significant impact. The method adopted to derive riverine TA is reasonable to infer average values at sub-regional scale, but clearly it does not impart seasonal patterns or localised heterogeneity due to diverse land-use in the catchment of the sub-region.

Secondly derived $\mathrm{pCO}_{2}$ is highly sensitive to DIC and TA error (Fig. 3), hence a reasonable error in the estimate of one of these variables (e.g. 5\%) may result in a significant error (e.g. a factor of two) in $\mathrm{pCO}_{2}$. If the errors in the master variables have the same sign the final error will be lower as the two errors compensate each other when the carbonate system is solved, but as those two variables are simulated independently in the model, the errors could also magnify: for instance an overestimation of primary production would cause an underestimation of DIC during the bloom and a contemporary overestimation of TA (due to larger nutrient uptake), exacerbating the error in $\mathrm{pCO}_{2}$.

Finally, the uncertainty in the carbonate system itself is still significant, both in the observations and in the model. Despite the good quality of the observations and regardless of the set of constants used, the standard procedure recommended by the international community to solve the carbonate system was not able to provide a $\mathrm{pH}$ estimate within a reasonable error. This is due to a significant structural and parameter uncertainty in carbonate chemistry, particularly in the shelf sea waters. Most of this uncertainty is related to the complexity of the definition of TA (Dickson, 1981); this is defined in terms of "hydrogen ions equivalent". In seawater TA, the most considered (and important) constituents are known (bicarbonate, carbonate, borate, phosphate, silicate, sulphate and fluoride) but recent studies evidenced that in some cases weaker acids such as the organic acids cannot be neglected (Muller and Bleie, 2008), particularly in productive areas like the shelf seas. Furthermore, some of the main components are commonly calculated using correlation generally derived from few oceanic samples (e.g. the Uppström (1974) correlation to derive borate concentration from salinity). It is possible that these do not provide the best estimate for shelf sea regimes. This supports previous findings that suggest that the Millero et al. (1993) error estimates are optimistic and that 'overconstraining' the 


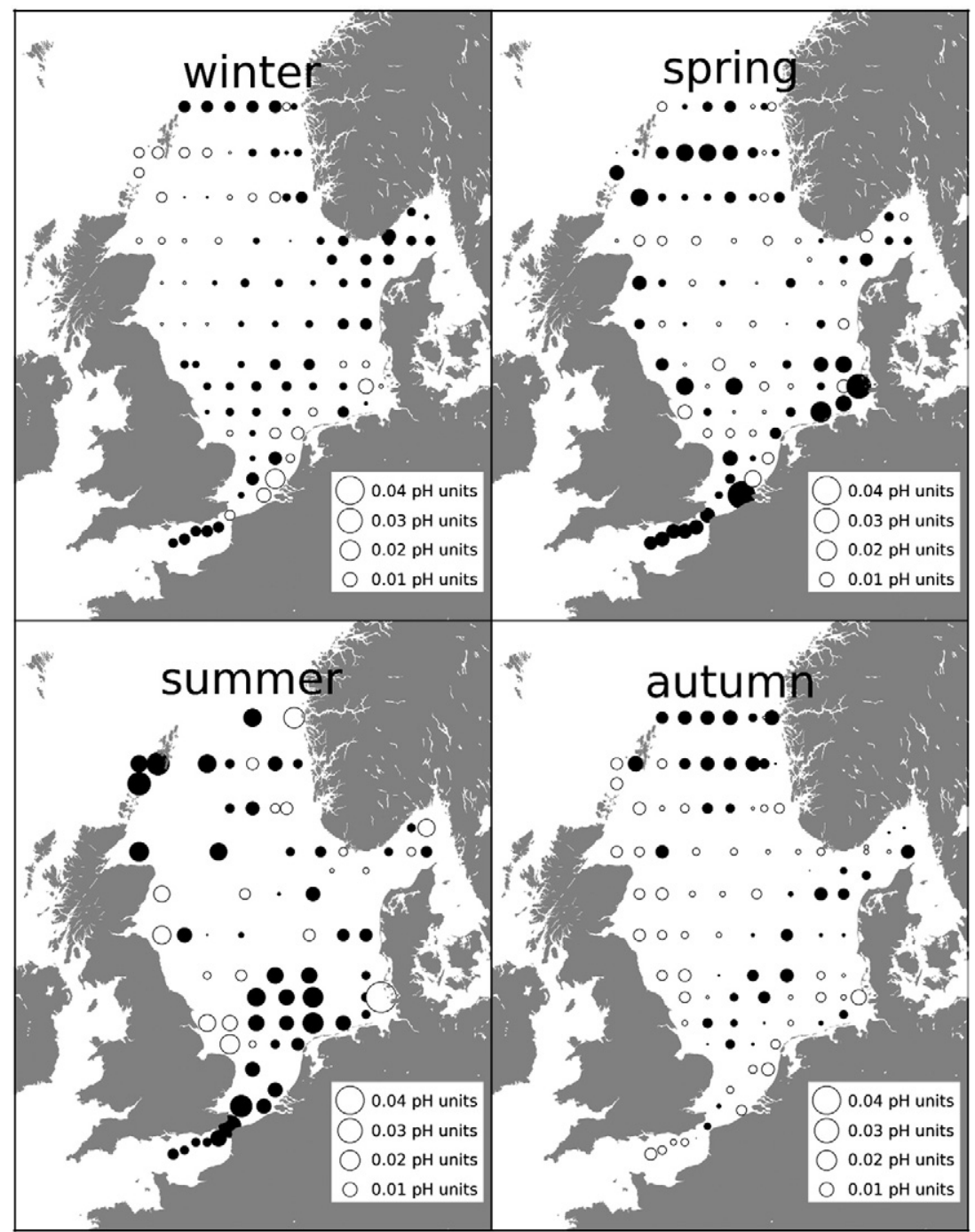

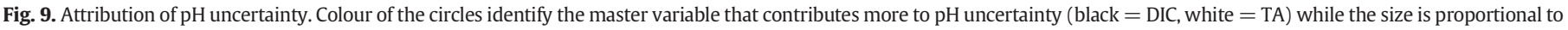
the total uncertainty on pH due to error in DIC and TA.

carbonate system in observational programmes is inappropriately labelled and in fact highly desirable.

In the model there are other sources of uncertainty to consider, related to all the biogeochemical processes concurring in the determination of the master variables. These appear to dominate over the uncertainty intrinsic to the formulation of the carbonate system, as there is no significant difference between the metrics obtained from validation with observed $\mathrm{pH}$ and $\mathrm{pCO}_{2}$, and the ones obtained with the calculated value of those (i.e. removing the uncertainty on the carbonate chemistry because simulated and observed value are both calculated under the same assumptions).

The analysis of $\mathrm{pH}$ uncertainty helps to identify primary production and riverine input as the two processes largely responsible. The largest uncertainty occurs during the productive seasons and it is driven by DIC that is indeed underestimated in these seasons, particularly in the southern North Sea (see figure S6). Primary production and the consequent community respiration are the two processes that mostly force the DIC dynamics. Given the absence of measures of the organic pool, it is not possible to determine if this is due to an overestimation of primary production or vice-versa to an underestimation of respiration activity. Several factors can contribute to error in the estimation of primary production, one being parameter uncertainty (in particular maximum growth rate, Chl:C ratio), another one being poor estimates of nutrient concentration. Furthermore in the coastal area a great source of uncertainty is linked to poor quality of the riverine forcing. One example of the importance of riverine input is the high $\mathrm{pH}$ uncertainty due to TA occurring in the coastal areas, where this variable is largely dependent on riverine alkalinity.

In the present state of the model, the consequences of carbonate system errors are limited as the carbonate system module has few feedbacks on ERSEM, one being the air-sea $\mathrm{CO}_{2}$ flux calculation: due to high errors in $\mathrm{pCO}_{2}$, the misestimates of instantaneous air-sea $\mathrm{CO}_{2}$ fluxes could be significant. However the strong negative feedback of the air-sea $\mathrm{CO}_{2}$ exchange process should prevent long term error propagation, and indeed long term estimates of air-sea $\mathrm{CO}_{2}$ flux from POLCOMS-ERSEM are in reasonable agreement with observations away from coastal regions (Wakelin et al., 2009). Further studies are needed to assess impact on longer timescales, particularly in these coastal regions, where there are many other variables influencing air-sea fluxes, e.g. wind speed: a large error in $\mathrm{pCO}_{2}$ (water) during a period of calm would potentially be less significant than a smaller error during a storm.

\section{Conclusions}

Despite all the uncertainties evidenced, the model demonstrated an acceptable ability to represent the fundamental processes of the carbonate system, and the potential, errors considered, for predicting 
trends in the carbonate system. The complexity of the model enables the replication of the high carbonate system heterogeneity of the North Western European Shelf ecosystem and to also study the OA trends. In this context, it is important to reduce the uncertainty on coastal carbonate chemistry biogeochemical processes (e.g. including some measures of organic carbon even in inorganic focussed observational programmes) and riverine forcing. In the absence of better data coming from monitoring programmes, it will be helpful to extend the ensemble approach generally used for physical forcing and parameterisation to the equivalent biogeochemical component e.g. running the model with different values of some key biological parameters or of the riverine input. Moreover, improved resolution of river plumes/coastal currents would be highly desirable in this shelf-scale context.

The model has also the potential to study the impacts of OA on the ecosystem. Despite the high uncertainty in observed impacts some general information is emerging from recent OA research (Bellerby et al., 2008; Kroeker et al., 2010; Liu et al., 2010). The results shown in this paper suggest that, in order to avoid error propagation in the model, it is preferable (if physiologically realistic) to parameterize impacts based on the master variables (DIC and TA), as these are estimated with reasonable confidence, or at most based on $\mathrm{pH}$, as this is less sensitive. However linking ecosystem processes (e.g. primary production) to sensitive variables will increase the uncertainty on those processes and potentially propagate the errors of the carbonate system through the whole ecosystem model decreasing its reliability.

\section{Acknowledgments}

Authors thank H. Thomas and R. Bellerby for providing the data and the helpful discussion. This work was funded by the Theme 6 of the EC seventh framework programme through the "Marine Ecosystem Evolution in a Changing Environment" (MEECE No 212085) and the "European Project on Ocean Acidification" (EPOCA No211384) Collaborative Projects and by the NERC/DECC/Defra funded UK Ocean Acidification Program through the project "Regional ecosystem \& biogeochemical impacts of Ocean Acidification - a Modelling study" (ROAM, NE/H017372/1).

\section{Appendix A. Metrics definition}

$$
\begin{aligned}
& R M S E=\sqrt{\frac{\sum_{n}\left(D_{n}-M_{n}\right)^{2}}{N}} \\
& \% R M S E=100 \bar{D} \sqrt{\frac{\sum_{n}\left(D_{n}-M_{n}\right)^{2}}{N}} \\
& \text { Bias }=\frac{\sum_{n}\left(D_{n}-M_{n}\right)}{N} \\
& \text { \%Bias }=\frac{100 \frac{\sum_{n}\left(D_{n}-M_{n}\right)}{\bar{D}} \frac{N}{D_{n}-M_{n} \mid}}{N F=\sum_{n}} \\
& R 2=\frac{\left(\sum_{n}\left(D_{n}-\bar{D}\right)\left(M_{n}-\bar{M}\right)\right)^{2}}{\sum_{n}\left(D_{n}-\bar{D}\right)^{2} \sum_{n}\left(M_{n}-\bar{M}\right)^{2}} \\
& M E=1-\frac{\sum_{n}\left(D_{n}-M_{n}\right)^{2}}{\sum_{n}\left(D_{n}-\bar{D}\right)^{2}}
\end{aligned}
$$

where $\mathrm{D}$ is data, $\mathrm{M}$ is corresponding model result, $\mathrm{n}$ is the running index along the $\mathrm{N}$ observations and the overbar indicates the arithmetic mean of the values.

\section{Appendix B. Supplementary data}

Supplementary data to this article can be found online at http:// dx.doi.org/10.1016/j.jmarsys.2012.04.006.

\section{References}

Allen, J.I., Holt, J.T., Blackford, J., Proctor, R., 2007. Error quantification of a high-resolution coupled hydrodynamic-ecosystem coastal-ocean model: part 2. Chlorophyll-a, nutrients and SPM. J. Mar. Syst. 68, 381-404.

Andersson, P.M., Andersson, L.S., 2006. Long term trends in the seas surrounding Sweden. Part one - Nutrients. SMHI, Norrköping (DK). p. 235.

Baretta, J.W., Ebenhöh, W., Ruardij, P., 1995. The European regional seas ecosystem model, a complex marine ecosystem model. Neth. J. Sea Res. 33, 233-246.

Bates, N.R., 2007. Interannual variability of the oceanic CO2 sink in the subtropical gyre of the North Atlantic Ocean over the last 2 decades. J. Geophys. Res. 112, C09013.

Bellerby, R.G.J., Olsen, A., Furevik, T., Anderson, L.A., 2005. Response of the surface ocean $\mathrm{CO} 2$ system in the Nordic Seas and North Atlantic to climate change. In: Drange, $\mathrm{H}_{\text {. }}$ Dokken, T.M., Furevik, T., Gerdes, R., Berger, W. (Eds.), Climate Variability in the Nordic Seas: Geophysical Monograph Series. AGU, pp. 189-198.

Bellerby, R.G.J., Schulz, K.G., Riebesell, U., Neill, C., Nondal, G., Heegaard, E., Johannessen, T., Brown, K.R., 2008. Marine ecosystem community carbon and nutrient uptake stoichiometry under varying ocean acidification during the PeECE III experiment Biogeosciences 5, 1517-1527.

Blackford, J.C., 2010. Predicting the impacts of ocean acidification: challenges from an ecosystem perspective. J. Mar. Syst. 81, 12-18.

Blackford, J.C., Gilbert, F.J., 2007. pH variability and CO2 induced acidification in the North Sea. J. Mar. Syst. 64, 229-241.

Blackford, J.C., Allen, J.I., Gilbert, F.J., 2004. Ecosystem dynamics at six contrasting sites: a generic modelling study. J. Mar. Syst. 52, 191-215.

Borges, A.V., Frankignoulle, M., 1999. Daily and seasonal variations of the partial pressure of $\mathrm{CO} 2$ in surface seawater along Belgian and southern Dutch coastal areas. J. Mar. Syst. 19, 251-266.

Borges, A.V., Gypens, N., 2010. Carbonate chemistry in the coastal zone responds more strongly to eutrophication than ocean acidification. Limnol. Oceanogr. 55, 346-353.

Caldeira, K., Wickett, M.E., 2003. Anthropogenic carbon and ocean pH. Nature 425, 365 365.

Dickson, A.G., 1981. An exact definition of total alkalinity and a procedure for the estimation of alkalinity and total inorganic carbon from titration data. Deep Sea Res. Part A 28, 609-623.

Dickson, A.G., 1990. Thermodynamics of the dissociation of boric acid in synthetic seawater from 273.15 to 318.15 K. Deep Sea Res. Part A 37, 755-766.

Dickson, A.G., 2010. The carbon dioxide system in seawater: equilibrium chemistry and measurements. In: Riebesell, U., Fabry, V.J., Hansson, L., Gattuso, J.P. (Eds.), Guide to Best Practices for Ocean Acidification Research and Data Report. Publications Office of the European Union, Luxembourg.

Dickson, A.G., Millero, F.J., 1987. A comparison of the equilibrium constants for the dissociation of carbonic acid in seawater media. Deep Sea Res. Part A 34, 1733-1743.

Dickson, A.G., Sabine, C.L., Christian, J.R., 2007. Guide to Best Practices for Ocean Co2 Measurements Special Publication 3. PICES, p. 191.

Doney, S.C., Fabry, V.J., Feely, R.A., Kleypas, J.A., 2009. Ocean acidification: the other $\mathrm{CO}_{2}$ problem. Ann. Rev. Mar. Sci. 1, 169-192.

Dore, J.E., Lukas, R., Sadler, D.W., Church, M.J., Karl, D.M., 2009. Physical and biogeochemical modulation of ocean acidification in the central North Pacific. Proc Natl. Acad. Sci. 106, 12235-12240.

Fabry, V.J., Seibel, B.A., Feely, R.A., Orr, J.C., 2008. Impacts of ocean acidification on marine fauna and ecosystem processes. ICES J. Mar. Sci. 65, 414-432.

Feely, R.A., Doney, S.C., Cooley, S.R., 2009. Ocean acidification: present conditions and future changes in a high- $\mathrm{CO}_{2}$ world. Oceanography 22, 36-47.

Geider, R.J., MacIntyre, H.L., Kana, T.M., 1997. Dynamic model of phytoplankton growth and acclimation: responses of the balanced growth rate and the chlorophyll a: carbon ratio to light, nutrient-limitation and temperature. Mar. Ecol. Prog. Ser $148,187-200$

Gypens, N., Lacroix, G., Lancelot, C., Borges, A.V., 2011. Seasonal and inter-annual variability of air-sea $\mathrm{CO} 2$ fluxes and seawater carbonate chemistry in the Southern North Sea. Prog. Oceanogr. 88, 59-77.

Hjalmarsson, S., Wesslander, K., Anderson, L.G., Omstedt, A., Perttilä, M., Mintrop, L. 2008. Distribution, long-term development and mass balance calculation of total alkalinity in the Baltic Sea. Cont. Shelf Res. 28, 593-601.

Holt, J.T., James, I.D., 2001. An s coordinate density evolving model of the northwest European continental shelf 1 , model description and density structure. J. Geophys. Res. 106.

Holt, J.T., Allen, J.I., Proctor, R., Gilbert, F., 2005. Error quantification of a high-resolution coupled hydrodynamic-ecosystem coastal-ocean model: part 1 model overview and assessment of the hydrodynamics. J. Mar. Syst. 57, 167-188.

Holt, J., Wakelin, S., Huthnance, J., 2009. Down-welling circulation of the northwest European continental shelf: a driving mechanism for the continental shelf carbon pump. Geophys. Res. Lett. 36, L14602.

Hoppe, C.J.M., Langer, G., Rokitta, S.D., Wolf-Gladrow, D.A., Rost, B., 2010. On CO2 pertubation experiments: over-determination of carbonate chemistry reveals inconsistencies. Biogeosci. Discuss. 7, 1707-1726.

Ingri, N., Kakolowicz, W., Sillén, L.G., Warnqvist, B., 1967. High-speed computers as a supplement to graphical methods-V: Haltafall, a general program for calculating the composition of equilibrium mixtures. Talanta 14, 1261-1286. 
Jørgensen, B.B., Bang, M., Blackburn, T.H., 1990. Anaerobic mineralization in marine sediments from the Baltic Sea-North Sea transition. Mar. Ecol. Prog. Ser. 59, 39-54.

Kim, H.-C., Lee, K., 2009. Significant contribution of dissolved organic matter to seawater alkalinity. Geophys. Res. Lett. 36, L20603.

Kroeker, K.J., Kordas, R.L., Crim, R.N., Singh, G.G., 2010. Meta-analysis reveals negative yet variable effects of ocean acidification on marine organisms. Ecol. Lett. 13, 1419-1434.

Lenhart, H.-J., Mills, D.K., Baretta-Bekker, H., van Leeuwen, S.M., der Molen, J.v., Baretta, J.W., Blaas, M., Desmit, X., Kühn, W., Lacroix, G., Los, H.J., Ménesguen, A., Neves, R., Proctor, R., Ruardij, P., Skogen, M.D., Vanhoutte-Brunier, A., Villars, M.T., Wakelin, S.L., 2010. Predicting the consequences of nutrient reduction on the eutrophication status of the North Sea. J. Mar. Syst. 81, 148-170.

Lewis, E., Wallace, D., 1998. Program developed for $\mathrm{CO}_{2}$ system calculations. ORNL/ CDIAC.

Lewis, K., Allen, J.I., Richardson, A.J., Holt, J.T., 2006. Error quantification of a high resolution coupled hydrodynamic-ecosystem coastal-ocean model: part3, validation with continuous plankton recorder data. J. Mar. Syst. 63, 209-224.

Liu, J., Weinbauer, M.G., Maier, C., Dai, M., Gattuso, J.P., 2010. Effect of ocean acidification on microbial diversity and on microbe-driven biogeochemistry and ecosystem functioning. Aquat. Microb. Ecol. 61, 291-305.

McElligott, S., Byrne, R.H., Lee, K., Wanninkhof, R., Millero, F.J., Feely, R.A., 1998. Discrete water column measurements of $\mathrm{CO} 2$ fugacity and pHT in seawater: a comparison of direct measurements and thermodynamic calculations. Mar. Chem. 60, 63-73.

Mehrbach, C., Culberson, C.H., Hawley, J.E., Pytkowicz, R.M., 1973. Measurement of the apparent dissociation constants of carbonic acid in seawater at atmospheric pressure. Limnol. Oceanogr. 18, 897-907.

Millero, F.J., 1995. Thermodynamics of the carbon dioxide system in the oceans Geochim. Cosmochim. Acta 59, 661-677.

Millero, F.J., Byrne, R.H., Wanninkhof, R., Feely, R., Clayton, T., Murphy, P., Lamb, M.F., 1993. The internal consistency of $\mathrm{CO}_{2}$ measurements in the equatorial Pacific. Mar. Chem. 44, 269-280.

Millero, F.J., Lee, K., Roche, M., 1998. Distribution of alkalinity in the surface waters of the major oceans. Mar. Chem. 60, 111-130.

Millero, F.J., Pierrot, D., Lee, K., Wanninkhof, R., Feely, R., Sabine, C.L., Key, R.M., Takahashi, T., 2002. Dissociation constants for carbonic acid determined from field measurements. Deep-Sea Res. I Oceanogr. Res. Pap. 49, 1705-1723.

Muller, F.L.L., Bleie, B., 2008. Estimating the organic acid contribution to coastal seawate alkalinity by potentiometric titrations in a closed cell. Anal. Chim. Acta 619, 183-191.

Nash, J.E., Sutcliffe, J.V., 1970. River flow forecasting through conceptual models part - a discussion of principles. J. Hydrol. 10, 282-290.

Orr, J.C., Fabry, V.J., Aumont, O., Bopp, L., Doney, S.C., Feely, R.A., Gnanadesikan, A. Gruber, N., Ishida, A., Joos, F., Key, R.M., Lindsay, K., Maier-Reimer, E., Matear, R. Monfray, P., Mouchet, A., Najjar, R.G., Plattner, G.-K., Rodgers, K.B., Sabine, C.L., Sarmiento, J.L., Schlitzer, R., Slater, R.D., Totterdell, I.J., Weirig, M.-F., Yamanaka, Y., Yool, A., 2005. Anthropogenic ocean acidification over the twenty-first century and its impact on calcifying organisms. Nature 437, 681-686.

OSPAR, 1996. Report of the modelling workshop on eutrophication issues. Ospar report, Den Haag, p. 86

Pätsch, J., Lenhart, H.-J., 2004. Daily Loads of Nutrients, Total Alkalinity, Dissolved Inorganic Carbon and Dissolved Organic Carbon of the European Continental Rivers for the Years 1977-2002. Berichte aus dem Zentrum für Meeres- und Klimaforschung Reihe B, Ozeanographie, 48, 159 pp.

Pörtner, H., 2008. Ecosystem effects of ocean acidification in times of ocean warming: a physiologist's view. Mar. Ecol. Prog. Ser. 373, 203-217.

Proctor, R., James, I.D., 1996. A fine-resolution 3D model of the Southern North Sea. J. Mar. Syst. 8, 285-295.

Raymond, P.A., Oh, N.-H., Turner, R.E., Broussard, W., 2008. Anthropogenically enhanced fluxes of water and carbon from the Mississippi River. Nature 451, 449-452.
Robbins, L.L., Hansen, M.E., Kleypas, J.A., Meylan, S.C., 2010. CO2calc-a user-friendly seawater carbon calculator for Windows, Max OS X, and iOS (iPhone). U.S. Geological Survey Open-File Report, p. 17.

Sabine, C.L., Feely, R.A., Gruber, N., Key, R.M., Lee, K., Bullister, J.L., Wanninkhof, R., Wong, C.S., Wallace, D.W.R., Tilbrook, B., Millero, F.J., Peng, T.-H., Kozyr, A., Ono, T., Rios, A.F., 2004. The oceanic sink for anthropogenic CO2. Science 305, 367-371. Santana-Casiano, J.M., González-Dávila, M., Rueda, M.-J., Llinás, O., González-Dávila, E.-F., 2007. The interannual variability of oceanic $\mathrm{CO} 2$ parameters in the northeast Atlantic subtropical gyre at the ESTOC site. Global Biogeochem. Cycles 21, GB1015.

Santos, I.R., Glud, R.N., Maher, D., Erler, D., Eyre, B.D., 2010. Diel coral reef acidification driven by porewater advection in permeable carbonate sands, Heron Island, Great Barrier Reef. Geophys. Res. Lett. 38, L03604.

Shutler, J.D., Smyth, T.J., Saux-Picart, S., Wakelin, S.L., Hyder, P., Orekhov, P., Grant, M.G., Tilstone, G.H., Allen, J.I., 2011. Evaluating the ability of a hydrodynamic ecosystem model to capture inter- and intra-annual spatial characteristics of chlorophyll-a in the north east Atlantic. J. Mar. Syst. 88, 169-182.

Smith, G., Haines, K., 2009. Evaluation of the S(T) assimilation method with the Argo dataset. Q. J. R. Meteorol. Soc. 135, 739-756. http://dx.doi.org/10.1002/qj.395.

Smyth, T.J., Moore, G.F., Hirata, T., Aiken, J., 2006. Semianalytical model for the derivation of ocean color inherent optical properties: description, implementation, and performance assessment. Appl. Opt. 45, 8116-8131.

T.R. Society, 2005. Ocean acidification due to increasing atmospheric carbon dioxide. In: T.R. Society (Ed.), Policy Document. The royal society, p. 60.

Steinacher, M., Joos, F., Frölicher, T.L., Plattner, G.K., Doney, S.C., 2009. Imminent ocean acidification in the Arctic projected with the NCAR global coupled carbon cycleclimate model. Biogeosciences 6, 515-533.

Suykens, K., Schmidt, S., Delille, B., Harlay, J., Chou, L., De Bodt, C., Fagel, N., Borges, A.V., 2011. Benthic remineralization in the northwest European continental margin (northern Bay of Biscay). Cont. Shelf Res. 31, 644-658.

Thomas, H., Schneider, B., 1999. The seasonal cycle of carbon dioxide in Baltic Sea surface waters. J. Mar. Syst. 22, 53-67.

Thomas, H., Bozec, Y., Elkalay, K., de Baar, H.J.W., 2004. Enhanced open ocean storage of CO2 from shelf sea pumping. Science 304, 1005-1008.

Thomas, H., Bozec, Y., de Baar, H.J.W., Elkalay, K., Frankignoulle, M., Schiettecatte, L.S., Kattner, G., Borges, A.V., 2005. The carbon budget of the North Sea. Biogeosciences 2, 87-96.

Thomas, H., Friederike Prowe, A.E., van Heuven, S., Bozec, Y., de Baar, H.J.W., Schiettecatte, L.-S., Suykens, K., Koné, M., Borges, A.V., Lima, I.D., Doney, S.C., 2007. Rapid decline of the CO2 buffering capacity in the North Sea and implications for the North Atlantic Ocean. Global Biogeochem. Cycles 21, GB4001.

Thomas, H., Schiettecatte, L.S., Suykens, K., Koné, Y.J.M., Shadwick, E.H., Prowe, A.E.F., Bozec, Y., de Baar, H.J.W., Borges, A.V., 2009. Enhanced ocean carbon storage from anaerobic alkalinity generation in coastal sediments. Biogeosciences 6, 267-274.

Uppström, L.R., 1974. The boron/chlorinity ratio of deep-sea water from the Pacific Ocean. Deep Sea Res.Oceanogr. Abstr. 21, 161-162.

Wakelin, S., Holt, J., Proctor, R., 2009. The influence of initial conditions and open boundary conditions on shelf circulation in a 3D ocean-shelf model of the North East Atlantic. Ocean Dyn. 59, 67-81.

Wakelin, S.L., Holt, J.T., Blackford, J.C., Allen, J.I., Butenschön, M., Artioli, Y., in press. Modeling the carbon fluxes of the northwest European continental shelf: validation and budgets. J. Geophys. Res. http://dx.doi.org/doi:10.1029/2011JC007402.

Weiss, R.F., 1974. Carbon dioxide in water and seawater: the solubility of a non-ideal gas. Mar. Chem. 2, 203-215.

Zeebe, R.E., Wolf-Gradow, D., 2001. $\mathrm{CO}_{2}$ in Seawater: Equilibrium, Kinetics, Isotopes. Elsevier Science Publishers. 